\title{
Navicular Bone
}

National Cancer Institute

\section{Source}

National Cancer Institute. Navicular Bone. NCI Thesaurus. Code C33162.

An oval-shaped bone of the tarsus found on the medial side of the foot. 